\title{
ОСОБЛИВОСТІ МОДУЛЬНО-РЕЙТИНГОВОЇ СИСТЕМИ ПРИ ВИКЛАДАННІ ДИСЦИПЛІНИ “ФІЗИЧНІ МЕТОДИ АНАЛІЗУ ТА МЕТРОЛОГІЯ” ДЛЯ СТУДЕНТІВ-ФАРМАЦЕВТІВ
}

\author{
М. В. Вісьтак, Е. І. Личковський, Р. В. Фафула \\ Львівський національний медичний університет імені Данила Галицького
}

\section{PECULIARITIES OF MODULE-RATING SYSTEM IN TEACHING OF DISCIPLINE "PHYSICAL METHODS OF ANALYSIS AND METROLOGY" FOR PHARMACEUTICAL STUDENTS}

\author{
M. V. Vistak, E. I. Lychkovskyi, R. V. Fafula \\ Lviv National Medical University by Danylo Halytskyi
}

\begin{abstract}
Розглянуто особливості модульно-рейтингової системи при викладанні навчальної дисципліни “Фізичні методи аналізу та метрологія” для студентів-фармацевтів. Показано переваги кредитно-модульної системи над традиційною системою навчання у вивченні і оцінюванні знань і вмінь студентів 3 даного курсу. Як показали дослідження, модульно-рейтингова система навчання підвищус якість підготовки фахівців 3 фармації.
\end{abstract}

The peculiarities of module-rating system in teaching of discipline "Physical methods of analysis and metrology" for pharmaceutical students were considered. It was shown the advantages of module-rating system over traditional system in studying and evaluation of students knowledge on this discipline. It was found that module-rating system of studying improves the quality of specialist preparation in pharmacy.

Вступ. Одним із основних принципів підготовки майбутніх фахівців відповідно до Закону України “Про вищу освіту" є інтеграція національної освіти в єдиний європейський і світовий простір. Україна в травні 2005 року приєдналась до Болонського процесу, що вимагає удосконалення навчально-методичної документації, яка відповідатиме єдиним критеріям і стандартам, зберігаючи при цьому традиції і досягнення української вищої школи [1].

Тому сучасні вимоги до навчання потребують індивідуального підходу до студента, формування системи об' єктивного оцінювання знань, умінь і навичок студентів. Головним завданням $\epsilon$ встановлення зв'язку європейської єдиної системи ECTS з національною чотирибальною системою оцінювання.

Основна частина. Основною метою кредитної модульної системи $є$ наближення української освітньої системи до європейської, підвищення якості навчання майбутніх фахівців, які зможуть конкурувати на міжнародних ринках праці.

Процес засвоєння знань завершується контролем і оцінюванням результатів навчання. Традиційна система контролю й оцінювання не забезпечує достатньої об' єктивності оцінки знань. Аналіз чотирибаль- ної системи оцінювання знань показав, що студент працює нерівномірно і несистематично. Запровадження модульно-рейтингової системи навчання спонукає студентів до систематичної навчальної праці і дає змогу досягти оптимальних навчальних результатів.

У своїй майбутній діяльності фармацевт буде приймати рішення щодо вирішення різних проблемних ситуацій на робочому місці в аптечній системі, науково-виробничих комплексах. Тому важливим $€$ при підготовці спеціалістів навчити студентів самостійно орієнтуватись у великих об'ємах нової інформації. Таким чином, самостійне навчання повинно бути однією із основних складових сучасної професійної підготовки фармацевта. І тут основна роль належить викладачу, який організовує і контролює самостійну роботу студентів.

Наше дослідження передбачає розробку оптимального змісту курсу “Фізичні методи аналізу та метрологія”, професійно-орієнтованого, а також використання відповідних інноваційних методів навчання. Важливим $\epsilon$ інтеграція знань 3 фізики, математики, фізичних методів аналізу та метрології, а також фахових дисциплін. У фахових дисциплінах для якісних

() М. В. Вісьтак, Е. І. Личковський, Р. В. Фафула 
і кількісних досліджень при розробці нових лікарських препаратів використовують знання метрології і фізичних методів досліджень. Завданням курсу “Фізичні методи аналізу та метрологія” є опанування методами і підходами для дослідження якісних і кількісних характеристик фармацевтичних препаратів, інтерпретації та обробки результатів у фармації.

3 цією метою дисципліна “Фізичні методи аналізу та метрологія” включає в себе один модуль, який у свою чергу поділяється на чотири змістових модулі, що разом становить 1,5 кредиту. Один кредит в Ук- раїні згідно з Свропейською кредитно-трансферною системою (Europen Credit Transfer System - ECTS) визначено на рівні 36 годин, з яких 55,6 \% складає аудиторне навантаження, а усе інше - самостійна, індивідуальна, науково-дослідна та інші види робіт. Змістові модулі (табл. 1) являють собою систему навчальних елементів даної дисципліни, які передбачені навчальним планом, мають самостійну, логічну структуру та зміст. Кожен змістовий модуль має певне “ядро", навколо якого структурується весь зміст.

Таблиця 1. Структура залікового кредиту - модуля:

\begin{tabular}{|c|c|c|c|}
\hline Тема & $\begin{array}{l}\text { Лекції } \\
\text { (год) }\end{array}$ & $\begin{array}{c}\text { Лабор.-практ. } \\
\text { заняття } \\
\text { (год) }\end{array}$ & $\begin{array}{l}\text { СРС } \\
\text { (год) }\end{array}$ \\
\hline \multicolumn{4}{|c|}{ Змістовий модуль 1. Основи теоретичної метрології та її роль у фармації } \\
\hline $\begin{array}{l}\text { Прямі і непрямі вимірювання. Похибки вимірювань. Показники метрологічної } \\
\text { надійності. Основні відомості щодо стандартизації }\end{array}$ & 2 & 4 & \\
\hline \multicolumn{4}{|c|}{ Змістовий модуль 2. Механічні, електричні, оптичні, магнітні та термічні методи дослідження у фармації } \\
\hline Термоаналітичні методи дослідження речовин & \multirow{3}{*}{2} & 2 & \\
\hline $\begin{array}{l}\text { Механічні методи. } \\
\text { Електричні та магнітні методи. Електрофорез. Види електрофорезу }\end{array}$ & & 2 & 11 \\
\hline Оптичні методи дослідження речовин & & 2 & 2 \\
\hline \multicolumn{4}{|c|}{$\begin{array}{c}\text { Змістовий модуль 3. Спектрофотометричні методи. Методи радіоспектроскопії. Люмінесцентні методи } \\
\text { дослідження }\end{array}$} \\
\hline $\begin{array}{l}\text { Спектрофотометрія. УФ і ІЧ-спектрофотометрія. Інтерпретація УФ і ІЧ спектрів } \\
\text { речовин }\end{array}$ & \multirow{4}{*}{2} & 4 & \multirow{4}{*}{3} \\
\hline Спектроскопія комбінаційного розсіювання & & \multirow{4}{*}{2} & \\
\hline Електронний парамагнітний резонанс (ЕПР) & & & \\
\hline Ядерний магнітний резонанс & & & \\
\hline Люмінесцентні методи дослідження & 2 & & 2 \\
\hline \multicolumn{4}{|l|}{ Змістовий модуль 4. Рентгеноструктурний аналіз у фармації } \\
\hline Дослідження радіоактивних препаратів. Рентгенівські методи & 2 & 2 & 3 \\
\hline Підсумковий модульний контроль № 1 “Фізичні методи аналізу та метрологія ” & & 2 & \\
\hline Індивідуальна робота & & & 3 \\
\hline
\end{tabular}

Так, змістовий перший модуль має назву “Основи теоретичної метрології та їі роль у фармаціі”. В ньому передбачено повторення $з$ курсу вищої математики похибок вимірювань, ознайомлення з методами вимірювання фізичних величин, і можливість їх використання у методиках дослідження якісних i кількісних характеристик лікарських препаратів. Крім змісту кожного змістового модуля, підбирались спеціальні методи навчання. Доцільним є використання проблемних ситуацій. Так, наприклад, при вивченні змістового модуля "Рентгеноструктурний аналіз у фармації” повторювались такі питання з фізики, як: механізм виникнення рентгенівського випромінювання, його природа і властивості, види рентгенівських спектрів. Це дозволить студентам швидше опанувати методи якісного і кількісного рентгеноструктур- ного аналізу, аналізувати рентгенограми хімічних сполук, а саме лікарських речовин.

Кредитно-модульна система передбачає організацію навчального процесу і контроль засвоєних знань і вмінь. 3 точки зору мінімізації затрати часу найбілыш оптимальним є тестовий контроль. Особливою вимогою до тестів $€$ їх валідність і надійність. Валідність передбачає відповідність між завданнями тесту і вимогами навчальної програми. Завдання тестів не повинні містити другорядних питань, щоб не упустити головного, не повинна надаватись перевага лише теоретичним або практичним елементам навчального матеріалу. Слід пам'ятати, що надійність тесту залежить від кількості завдань у тесті, а також від кількості їх відповідей. Тести повинні бути чітко сформульованими, однозначними, включати лише головні 
елементи знань. В основу модульно-рейтингової системи була покладена ідея поточного контролю навчальної роботи студентів. Завдяки цьому була забезпечена систематичність і рівномірність аудиторної та самостійної роботи студентів протягом усього семестру. Кожне практичне і лабораторне заняття оцінювалось відповідно до розроблених на кафедрі біофізики критеріїв оцінювання. Студенти, які були відсутні на занятті з будь-яких причин, отримували нульову поточну оцінку. Максимально можлива кількість балів, яку може набрати студент за семестр при поточному контролі змістових модулів, становить 117 балів. Для заохочування студентів за додаткову творчу роботу з дисципліни (наприклад, у студентській науковій конференції, студентських олімпіадах) нараховують додаткові три бали. Таким чином студент максимально може набрати на поточному навчанні 120 балів. Повна рейтингова оцінка визначається як сума балів за підсумками поточного контролю і підсумкового модульного контролю, на якому студент може максимально набрати 80 балів. Максимальна кількість балів, яку може набрати студент по всіх видах контролю, становить 200 балів. Бали, набрані студентом за різні види діяльності впродовж семестру, сумуються і конвертуються в чотирибальну шкалу таким чином:

\begin{tabular}{|c|c|}
\hline Оцінка в балах & $\begin{array}{c}\text { Оцінка за національною } \\
\text { шкалою }\end{array}$ \\
\hline $170-200$ & Відмінно (5) \\
\hline $140-169$ & Добре (4) \\
\hline $122-139$ & Задовільно (3) \\
\hline $0-121$ & Незадовільно (2) \\
\hline
\end{tabular}

Студенти, які вивчили курс “Фізичні методи аналізу та метрологія”, з урахуванням кількості балів, набраних з дисципліни, ранжуються за шкалою ЕCTS таким чином:

\begin{tabular}{|c|c|}
\hline Оцінка ECTS & Статистичний показник \\
\hline A & Найкращі $10 \%$ студентів \\
\hline В & Наступні $25 \%$ студентів \\
\hline C & Наступні $30 \%$ студентів \\
\hline
\end{tabular}

\section{Література}

1. Вища освіта України і Болонський процес : навчальний посібник / за редакцією В. Г. Кременя. - Тернопіль : Навчальна книга-Богдан, 2004. - 384 с.

2. Сікорський П. І. Тестовий контроль знань в умовах кредитно-модульної системи навчання / П. І. Сікорський // Збірник наукових праць. - Львів : ФОП Корпан Б.І., 2009. T. 4. - C. 227-232.

\begin{tabular}{|c|c|}
\hline $\mathrm{D}$ & Наступні $25 \%$ студентів \\
\hline $\mathrm{E}$ & Останні $10 \%$ студентів \\
\hline $\mathrm{Fx}$ & Повторне складання \\
\hline $\mathrm{F}$ & $\begin{array}{c}\text { Обов'язковий повторний курс } \\
\text { навчання }\end{array}$ \\
\hline
\end{tabular}

Ранжування з присвоєння оцінок “A”, “B”, “C”, “'D”, “Е” проводиться для студентів даного курсу, які успішно завершили вивчення дисципліни. Оцінка Fx виставляється студентам, які набрали мінімальну кількість балів за поточну навчальну діяльність, що при вивченні в нашому курсі становлять 72 бали, але яким не зараховано підсумковий модульний контроль. Ця категорія студентів має право на перескладання підсумкового модульного контролю за затвердженим графіком. Повторне складання підсумкового модульного контролю дозволяється не більше двох разів.

Оцінка F виставляється студентам, які відвідали всі аудиторні заняття з модуля, але не набрали мінімальну кількість балів за поточну навчальну діяльність і не допущені до підсумкового модульного контролю. Цій категорії студентів може надаватись право на повторне вивчення модуля.

Оцінка ECTS конвертується у традиційну чотирибальну шкалу таким чином:

\begin{tabular}{|c|c|}
\hline Оцінка ECTS & $\begin{array}{c}\text { Оцінка за чотирибальною } \\
\text { шкалою }\end{array}$ \\
\hline $\mathrm{A}$ & 5 \\
\hline $\mathrm{B}, \mathrm{C}$ & 4 \\
\hline $\mathrm{D}, \mathrm{E}$ & 3 \\
\hline $\mathrm{Fx}, \mathrm{F}$ & 2 \\
\hline
\end{tabular}

Висновки. Як показали дослідження, модульнорейтингова система навчання є вдалою заміною традиційній системі навчання. Рівень засвоювання знань є вищим і більшою є об' єктивність в оцінюванні знань. Вона підвищує якість підготовки фахівців з фармації, забезпечує конкурентоспроможність випускників нашого вузу i, звичайно, підвищує престиж української вищої освіти в європейському світовому освітньому просторі.

3. Антонюк В. Модульно-рейтингова технологія і особистісно-орієнтована професійна підготовка спеціалістів / В. Антонюк, Ф. Гончар, М. Вісьтак // Актуальні проблеми викладання та навчання фізики у вищих освітніх закладах : матеріали III Міжнародної науково-методичної конференції. - Львів : Ліга-прес, 2009. - С. 66-71. 